\title{
"Factors affecting the application of IFRS through the perceptions of business managers and auditors in Vietnam"
}

\begin{tabular}{|c|c|}
\hline AUTHORS & $\begin{array}{l}\text { Dung-Thi Doan } \\
\text { Lan-Ngoc Thi Nguyen } \\
\text { Hai-Phan Thanh (D https://orcid.org/0000-0003-2176-9153 } \\
\text { R http://www.researcherid.com/rid/P-4732-2018 }\end{array}$ \\
\hline ARTICLE INFO & $\begin{array}{l}\text { Dung-Thi Doan, Lan-Ngoc Thi Nguyen and Hai-Phan Thanh (2020). Factors } \\
\text { affecting the application of IFRS through the perceptions of business managers } \\
\text { and auditors in Vietnam. Problems and Perspectives in Management, 18(1), 371- } \\
\text { 384. doi:10.21511/ppm.18(1).2020.32 }\end{array}$ \\
\hline DOI & http://dx.doi.org/10.21511/ppm.18(1).2020.32 \\
\hline RELEASED ON & Friday, 03 April 2020 \\
\hline RECEIVED ON & Sunday, 05 January 2020 \\
\hline ACCEPTED ON & Thursday, 19 March 2020 \\
\hline LICENSE & $\begin{array}{l}(c) E Y \quad E \\
\text { This work is licensed under a Creative Commons Attribution } 4.0 \text { International } \\
\text { License }\end{array}$ \\
\hline JOURNAL & "Problems and Perspectives in Management" \\
\hline ISSN PRINT & $1727-7051$ \\
\hline ISSN ONLINE & $1810-5467$ \\
\hline PUBLISHER & LLC "Consulting Publishing Company "Business Perspectives" \\
\hline FOUNDER & LLC "Consulting Publishing Company "Business Perspectives" \\
\hline
\end{tabular}

NUMBER OF REFERENCES

32

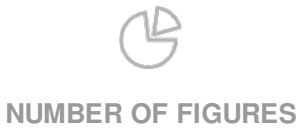

3
NUMBER OF TABLES

9

(C) The author(s) 2022. This publication is an open access article. 


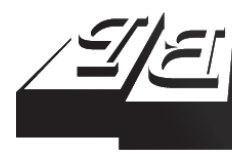

\section{BUSINESS PERSPECTIVES}

LLC "CPC "Business Perspectives" Hryhorii Skovoroda lane, 10, Sumy, 40022, Ukraine www.businessperspectives.org

Received on: $5^{\text {th }}$ of January, 2020 Accepted on: $19^{\text {th }}$ of March, 2020 Published on: $3^{\text {rd }}$ of April, 2020

(c) Dung-Thi Doan, Lan-Ngoc Thi Nguyen, Hai Thanh Phan, 2020

Dung-Thi Doan, Ph.D., Accounting Faculty, People's Police University of Technology and Logistics, Vietnam.

Lan-Ngoc Thi Nguyen, Ph.D. Accounting Faculty, Trade Union University, Vietnam.

Hai Thanh Phan, Ph.D, Associate Professor, Faculty of Accounting, Institute of Research and Development, Duy Tan University, Vietnam. (Corresponding author)
Dung-Thi Doan (Vietnam), Lan-Ngoc Thi Nguyen (Vietnam),

Hai Thanh Phan (Vietnam)

\section{FACTORS AFFECTING THE} APPLICATION OF IFRS THROUGH THE PERCEPTIONS OF BUSINESS MANAGERS AND AUDITORS IN VIETNAM

\begin{abstract}
The purpose of this study is to determine the factors that influence the application of the International Financial Reporting Standards (IFRS) in Vietnam through the perceptions of business managers and auditors. Combining qualitative and quantitative research methods based on a comprehensive analysis and aggregation of information available from various sources, the results of the questionnaire interviews of 500 managers and auditors currently working in Vietnam are offered. The results of the study show that factors affecting the applicability of IFRS in Vietnam are: legal basis for accounting activities; characteristics of enterprises; qualification and competency of the accounting teams; and corporate governance. The study also finds that governance factors and socio-economic and cultural conditions have an uncertain influence on the IFRS applicability. At the same time, there is no significant difference in awareness of the ability to apply IFRS between the group of enterprise managers and auditors and groups of people with different work experience. Among them, the qualifications and competencies of the accountant teams and the characteristics of enterprises are the two factors that have the strongest impact on the applicability of IFRS in Vietnam.
\end{abstract}

$\begin{array}{ll}\text { Keywords } & \text { application, IFRS, managers' perceptions, auditors, } \\ \text { Vietnam }\end{array}$

JEL Classification M41, M38, Q56

\section{INTRODUCTION}

Financial reporting is a tool for providing inclusive and truthful information on the financial position and performance of enterprises that serve and meet the information needs of various economic entities. The International Financial Reporting Standards (IFRS) are prepared by the International Accounting Standards Board (ISAB) and the International Financial Reporting Interpretations Committee (IFRIC). In the trend of the global economic integration, the preparation of financial statements in accordance with IFRS has increasingly received the support of countries and territories worldwide. According to the IFRS Foundation (2018) report, there were 144/166 (accounting for $87 \%$ ) countries and territories applying IFRS. However, there are still seven countries such as Bolivia, China, Egypt, India, Macao SAR, United States and Vietnam that have not applied IFRS. Nevertheless, currently Vietnam is also in the process of studying and drafting to apply the system of standards prescribed by ISAB. The application of the new special accounting standards system, in accordance with the general practices and regulations of numerous countries worldwide, is affected by several factors. 
So far, many authors have published their studies on factors affecting the application of accounting standards in general and IFRS in particular in the world and in Vietnam. Typically, there are studies by Zeghal and Mhedhbi (2006), Kolsi and Zehri (2013), Choi and Meek (2011), Zehri and Chouaibi (2013).

In Vietnam, there are studies by Hung (2016), Phuong (2013), Nguyen (2013), Cuc and Khanh (2018), Khue and Oanh (2019), Duc, Ha, and Phuoc (2019), Tran, Ha, Le, and Nguyen (2019), and Phuong (2019). Many studies have been conducted on factors affecting the application of IFRS in Vietnam; beside empirical studies were conducted to examine the awareness of various related groups of people such as accounting professionals, academic people, and auditors. However, there is also a need for other empirical research to supplement information and scientific grounds to help stakeholders make the best possible adjustments, improvements and best use IFRS in each other country in the days ahead.

\section{LITERATURE REVIEW AND HYPOTHESES DEVELOPMENT}

\subsection{Legal basis related to accounting}

The legal basis in the field of accounting is a system of legal documents issued by the State to apply the accounting work in practice. Up till now, several studies have agreed that the legal basis issued by the State affects the application and organization of accounting work. The legal system is considered a major factor affecting the national accounting system. Countries often have two different ways to form their own legal systems based on common law or code law. Nobes and Parker (1995), Dayanandan, Donker, Ivanof, and Karahan (2016) suggested that common law countries are less likely to issue detailed accounting regulations than code law countries. Therefore, legal status affected countries in Europe using IFRS.

Jaggi and Low (2000) examine the impact of the legal system on financial disclosure. The results suggest that enterprises in the common law countries have better financial disclosure compared to those in the code law countries. Kolsi and Zehri (2013) and Zehri and Chouaibi (2013) reveal that in many developing countries the legal basis is one of the factors explaining their choice for the IAS/ IFRS application.

In Vietnam, Phuong and Richard (2011) and Phuong (2013) identify the existence of parallel accounting standards and accounting regime, pointing to integration of Vietnam with general international accounting practices and revealing a unified management of the State in accounting. The aforementioned characteristics of the accounting system in Vietnam have shaped factors affecting the application of accounting standards. Hung (2016) also indicates that the legal basis is one of four factors affecting the application of accounting standards in Vietnam. The results of this study are based on the analysis of a survey of 250 people who worked as accountants at enterprises and were studying at Hanoi Industrial University in 2015.

Qualitative studies of Thinh (2019) and Khue and Oanh (2019) identify the legal system as one of the factors affecting IFRS application in Vietnam. From the above analysis, the authors make the following hypothesis:

H1: The legal basis has a positive influence on the application of IFRS in Vietnam.

\subsection{Qualification and competency of the accounting team}

The history of accounting development in other countries shows that the development of accounting relates to the level of accountants' education and professionalism (Choi \& Meek, 2011). Research in many countries shows that the more accountants with the university degree, the higher their ability to apply standards. This is appropriate because the knowledge in the training course will help accountants have better awareness of accounting science, be able to apply and select suitable accounting techniques and policies to maximize the benefits of their enterprises.

Doupnik and Salter (1995) and Street (2012) argue that the application of IFRS is a strategic social de- 
cision; therefore, the acceptance of these standards also depends on the level of experts in each country. Hegarty, Gielen, and Barros (2004) also mention certain qualification requirements (appropriately qualified individuals) when applying IFRS.

In Vietnam, Hung (2016) argues that accountants at enterprises, through qualifications, experience, capabilities and the role of chief accountants, have a significant impact on the application of accounting standards. Duc, Ha, and Phuoc (2019), based on a survey of 728 people (divided into three groups), show that the auditor group has a much higher level of acceptance and willingness to apply IFRS than the accountant group and the academic group. The reason that the academic group and accountant group think that the application of IFRS is hindered is that the qualification and competency of the accounting staff, especially at small and medium-sized enterprises, is low and uneven, mainly approaching from the perspective of accounting regimes and circulars rather than approaching from the perspective of accounting standards.

Previously, Nguyen (2013), while discussing the scale of non-financial factors affecting the application of accounting standards at small and medium-sized enterprises in Vietnam, revealed four non-financial factors that possibly affected the application of accounting standards, including the competency of accountants; documents guiding accounting practice; advice from the accounting community; and the attention of business owners. Given the above analysis, the authors put forward the following hypothesis:

H2: Qualifications and competencies of the accountant teams have a positive influence on IFRS application in Vietnam.

\subsection{Characteristics of enterprises}

The research on the characteristics of enterprises affecting the application of accounting standards and IFRS is carried out in different ways. However, the authors mainly focus on the main characteristics of enterprises, namely: business size, business sector, and business results.

Chow and Wong-Boren (1987) and Meek, Roberts, and Gray (1995) believe that scale is considered a factor that significantly affects the application of accounting standards. Large-scale enterprises have diversified activities in various fields; the complexity of economic operations is remarkably high and, therefore, the application of accounting standards will be higher. In addition, enterprises will have more financial resources to implement these new accounting standards. Smaller enterprises, meanwhile, find that the benefits of implementing standards are not enough to offset the resources they spend. Based on 106 listed companies in Germany and Austria, Affes and Callimaci (2007) suggest that business size has a positive impact on early adopting IAS/IFRS.

Meanwhile, Wallace and Naser (1995) suggest that profitability has a significant influence on the preparation and presentation of financial statements. The reason is that enterprises with high profitability often expand the business area and look for funding to implement new business options. Therefore, the figures on faithful and accurate financial statements are always one of the criteria for partners to consider before making business decisions.

J. Martínez, F. Martínez, and Diazaraque (2011), exploring 129 large listed enterprises on the Spanish stock market in 2005, showed that different fields of activity, the return on equity (ROE), the size and choice of the Big Four or Non-Big Four auditing firms had a different impact on the application of accounting methods and financial statement presentation in accordance with IFRS.

In Vietnam, Hung's (2016) study shows that the characteristics of enterprises have a positive influence on the application of accounting standards. These characteristics are the business size, business results, facilities and information systems of enterprises, the interest of business owners in the accounting work at their units. Survey results of Tran, Ha, Le, and Nguyen (2019) for 154 auditors in 2018 show that for listed enterprises in Vietnam, the larger they are, the higher the profitability (ROE) is and the greater the possibility of applying IFRS.

From the above analysis, the authors make the following hypothesis: 
H3: Characteristics of enterprises have a positive influence on the application of IFRS in Vietnam.

\subsection{State management of the accounting profession}

In Vietnam, research by Adams and Linh (2005) shows that governing the accounting profession follows the code law, so the consistency in accounting work will be high, manifested by the existence of a unified chart of accounts and financial statement forms. At the same time, the awareness of enterprise accountants is also mainly concerned with tax declaration. This is also an obstacle to applying Anglo-Saxon model accounting standards with high professional flexibility. Hung (2016) reveals that state management agencies, through the opinions of auditing firms, tax authorities, inspectors and associations, have an impact on the application of accounting standards at Vietnamese enterprises.

Another aspect of the approach, from the perspective of state management of the auditing profession, is whether it is mandatory for enterprises to be audited and audited by Big Four or Non-Big Four, because an auditing unit has a significant influence on the decision of enterprises to select and apply accounting standards. If an enterprise is audited by one of the major auditing firms, it is usually more interested in applying accounting standards. This opinion is expressed by Hung (2016), Tran, Ha, Le, and Nguyen (2019), Phuong (2019) for Vietnam that if the financial statements (FS) of an enterprise are audited and performed by Big Four, the level of compliance and application of IFRS will be higher than those that do not require mandatory auditing or being audited by Non-Big Four.

In Bahrain, Joshi and Ramadhan (2002) conclude that most enterprises applying IFRS are audited by Big Four auditing firms.

From the above analysis, the authors make the following hypothesis:

H4: State management of the accounting profession has a positive effect on the application of IFRS in Vietnam.

\subsection{Corporate governance}

Several studies point to the relationship between corporate governance and information disclosure and IFRS application in many countries around the world. Verriest, Gaeremynck, and Thornton (2013) indicate that the independence, function of the board of directors, the effectiveness of the committee's operations at enterprises affect the application of IFRS of listed companies in Europe in 2005. Goodwin, Ahmed, and Heaney (2009) conducted a research to see if a solid corporate governance system, especially in relation to the characteristics of the board of management and senior management, had an effect on the accuracy of the impact of accounting reported to shareholders or not. The study focuses on the relationship between corporate governance methods and accounting forecasting errors that arise when applying IFRS in Australian listed companies. Evidence shows that corporate governance mechanisms are related to the ability and importance of management forecasters.

In Vietnam, Nguyen (2013) and Hung (2016) show that the interest and investment of business owners affect the ability of enterprises to apply accounting standards, especially small and medium-sized enterprises in Vietnam. Hai, Tu, and Toan (2019) also suggest that corporate governance mechanism is one of the factors affecting the operating mechanism of auditing firms in Vietnam, thereby affecting the quality of auditing issued to customers.

H5: Corporate governance has a positive effect on the application IFRS in Vietnam.

\subsection{Political, economic and cultural conditions}

In terms of political factors related to the role of the State, Nobes and Parker (1995) suggest that the political institutions in which the State intervenes more or less in the economy and has a strong impact on the international accounting convergence process. This factor shows the influence on the development orientation and strategy associated with the process of international integration. Therefore, countries that are proactive in international integration have a tendency to apply more quickly, while some countries are cautious in the 
direction, so the application is limited (Thinh, 2019). Phuong and Richard (2011) argue that the process of forming Vietnamese accounting standards reflects the will of the Vietnamese State in the process of global economic integration to achieve political and economic goals. The promulgation of succession standards stems from the pressure to be accepted as a member of the WTO.

In terms of economic factors, Nobes and Parker (1995) argue that the accounting system evolves in line with the development of the national economy. The author cites Australia's accounting system that was previously relatively close to that of the UK due to its past colonial ties but is increasingly separate due to the increased trade transactions among Australia and the United States and Southeast Asian countries. From the growth perspective, the economy provides incentives for countries to adopt IFRS. Arpan and Radebaugh (1985) consider economic development as a basic variable profoundly affecting the development of accounting and other functions in society. This is in agreement with the research of Zeghal and Mhedhbi (2006), specifically in countries that have high economic growth and where the social functions of accounting for measurement purposes become more important. The size and complexity of business transactions and economic activity require a high quality accounting system.

Cultural factors have influenced the application of international standards in various countries. Therefore, countries that have a tendency to be cautious, avoid uncertainties, control by law and prudence will be less likely to immediately apply international accounting standards that will follow a roadmap. However, countries that have flexibility, the development of accounting profession, and ensuring disclosure will tend to adapt quickly and be easier to apply (Thinh, 2019). According to Nobes and Parker (1995), countries affected by the same cultural values often apply the same accounting standards. Thereby, Chamisa (2000), Zeghal and Mhedhbi (2006) proposed that the application of IFRS would be easier for developing countries with the Anglo-Saxon culture.

H6: Economic, political and cultural conditions have a positive influence on the application of IFRS in Vietnam.

\section{AIMS}

This study is conducted to achieve these objectives:

1) Overview of studies related to the factors affecting IFRS application.

2) Presentation of research models, research hypotheses and contents, including: research design, analysis of research results on factors affecting IFRS application through the perception of managers and auditors in Vietnam.

3) Conclusions and recommendations from the research findings, pointing to the limitations and future research directions.

\section{DATA AND RESEARCH METHODOLOGY}

\subsection{Research model}

As mentioned above, from several previously published studies, the authors give the model used for research (Figure 1).

\subsection{Data collection}

To examine the research hypotheses, the research team gathered data from interviews with managers and auditors currently working at a number of enterprises in Vietnam in different provinces. Data collection was conducted by direct questionnaire distribution, emailing and respondents answered by filling out an independent form or the response form via Google Drive. The results were analyzed by SPSS software; the scales were tested to determine reliability. The model was then established to examine the research hypotheses.

\subsection{Scale}

The study compiled a questionnaire with 32 observations, including 1 dependent variable, using a 5-step Likert scale (Point 1: Strongly disagree; Point 5: Strongly agree). Questionnaires and scales are checked and calibrated based on four factors: (1) Qualitative research, (2) Expert 


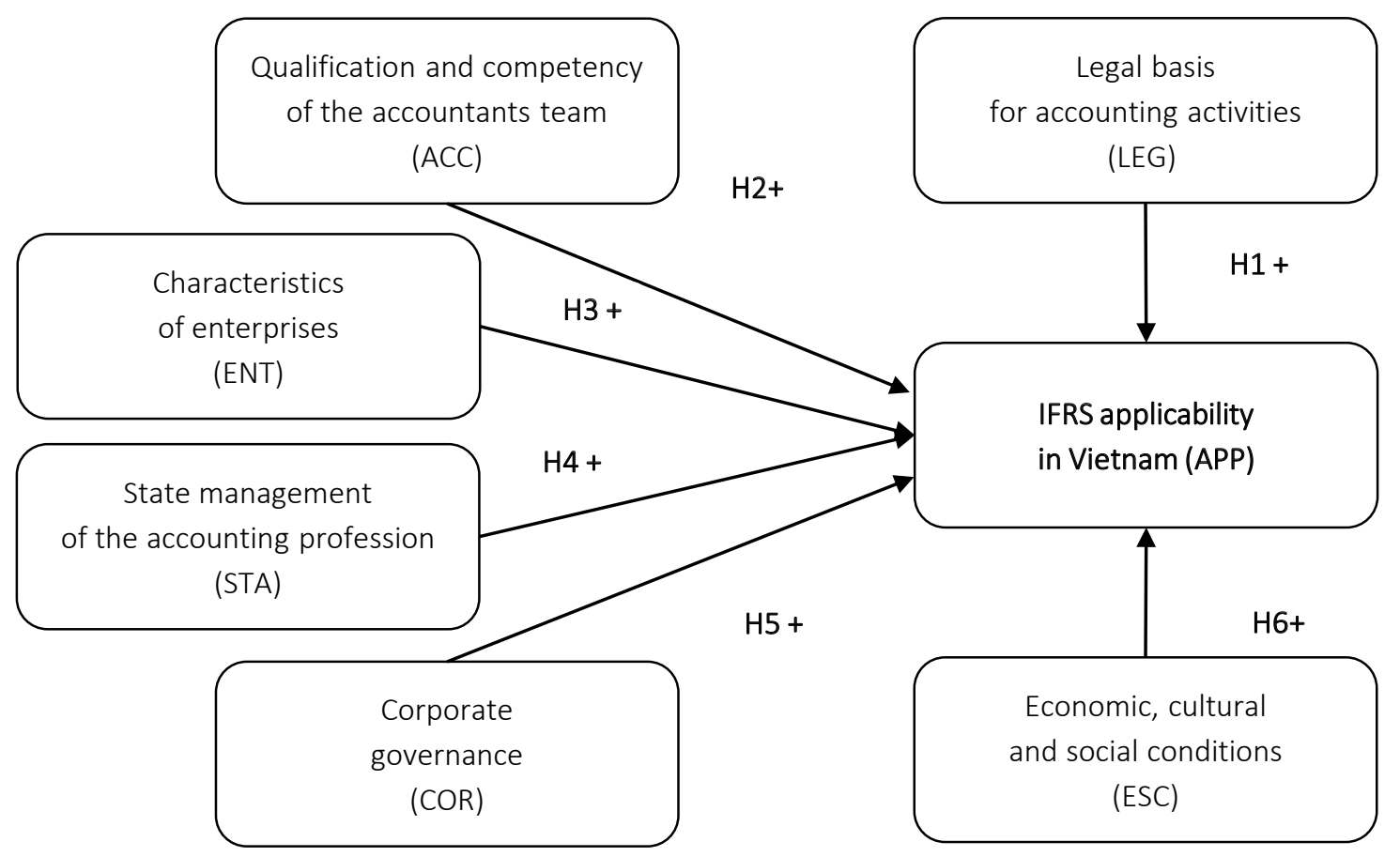

Figure 1. Research model

interviews (10 people), (3) In-depth interviews with 10 managers and auditors, and (4) Survey results of 20 samples.

The scale Legal basis for accounting activities (Symbol: LEG) includes five observations; the scale Qualification and competency of the accountant teams (Symbol: ACC) includes five observations; the scale Characteristics of enterprises (Symbol: ENT) includes five observations; the scale State management of the accounting profession (Symbol: STA) includes four observations; the scale Corporate governance (Symbol: COR) includes four observations; the scale Economic, cultural and social conditions (Symbol: ECS) includes four observations. The scale IFRS applicability in Vietnam (Symbol: APP) is shown by four observations. These scales are inherited and adjusted from the studies by Nguyen (2013), Hung (2016), Hai, Tu, and Toan (2019), Tran, Ha, Le, and Nguyen (2019), Khue and Oanh (2019), and Duc, Ha, and Phuoc (2019).

\subsection{Sample size}

The authors sent survey questionnaires to 1,000 people representing two groups: business managers (720 respondents) and auditors (280 respondents). The survey time started in February 2019.
By the end of December 2019, the authors had collected 545 votes of managers and 230 votes of auditors. As a result, after eliminating invalid answers, 500 questionnaires were processed and analyzed, including 200 responses of auditors and 300 responses of managers. Compared to the initial calculation with the questionnaire content consisting of $37 \mathrm{ob}-$ servations, the minimum number of needed samples is $37 \times 5=185$, the number of questionnaires put into processing is appropriate. Because according to Bollen (1989), the appropriate ratio for selecting a sample size with the number of parameters in the variable measurement analysis must be $5: 1$.

\subsection{Method of analysis}

The authors performed model verification by the SPSS 20 software in combination with the AMOS 20 through the following steps:

- Testing the scales: The scales were verified via three techniques: Cronbach's Alpha confidence coefficient, exploratory factor analysis (EFA), and confirmatory factor analysis (CFA).

- Model testing: The proposed research model and the research hypotheses were tested by the structural equation analysis (SEM) using the AMOS 20 software. 


\section{RESULTS}

Based on the survey results of 500 managers and auditors as mentioned above, the authors analyzed the degree of influence of each specific factor on the basis of the initial theoretical model. The result is presented below.

\subsection{Descriptive statistics of the research sample}

SPSS 20 software is used to conduct analysis in the study. Among the 500 managers and auditors, the information about the research sample (500 people) is detailed in Table 1.

\subsection{Testing Cronbach's Alpha coefficients}

The scale Legal basis for accounting activities (Symbol: LEG) includes five observations; the scale Qualification and competency of the accountant teams (Symbol: ACC) includes five observations; the scale Characteristics of enterprises (Symbol: ENT) includes five observations; the scale State management of the accounting profession (Symbol: STA) in- cludes four observations; the scale Corporate governance (Symbol: COR) includes four observations, and the scale Economic, cultural and social conditions (Symbol: ECS) includes four observations.

Cronbach's Alpha test results of the scales shown in Table 2 indicate that these scales all have Cronbach's Alpha coefficient $>0.6$ and the total correlation coefficient $>0.3$. Thus, the original 32 observed variables remain unchanged in the proposed model for use in the next EFA analysis.

\subsection{Exploratory factor analysis (EFA) and confirmatory factor analysis (CFA)}

\subsubsection{EFA analysis of scales}

Based on the survey results, after conducting exploratory factor analysis on data using the SPSS 16 software and removing variables with a factor loading coefficient less than 0.5 , the final results of exploratory factor analysis are shown in Table 3.

The above results show that $\mathrm{KMO}$ coefficient $>0.5$, Batlett test has p-value equal to $0.000<0.05$, av-

Table 1. Descriptive statistics of the survey sample

Source: Author's research.

\begin{tabular}{|c|c|c|}
\hline Characteristics & Frequency & Percentage, $\%$ \\
\hline Subject & $N=500$ & 100 \\
\hline Auditor & 200 & 40 \\
\hline Manager & 300 & 60 \\
\hline Work experience & $N=500$ & 100 \\
\hline Less than 5 years & 135 & 27 \\
\hline From 5 to 10 years & 190 & 38 \\
\hline From 10 to 15 years & 66 & 13.2 \\
\hline From 15 to 20 years & 84 & 16.8 \\
\hline More than 20 years & 25 & 5.0 \\
\hline
\end{tabular}

Table 2. Cronbach's Alpha test results of scales

Source: Author's research.

\begin{tabular}{|c|c|c|c|}
\hline Scales & Symbol & $\begin{array}{l}\text { Observed } \\
\text { variables }\end{array}$ & $\begin{array}{c}\text { Cronbach's } \\
\text { Alpha }\end{array}$ \\
\hline \multicolumn{4}{|c|}{ Independent variables } \\
\hline 1. Legal basis for accounting activities & LEG & 5 & 0.799 \\
\hline 2. Qualifications and competencies of the accountant teams & $\mathrm{ACC}$ & 5 & 0.763 \\
\hline 3. Characteristics of enterprises & ENT & 5 & 0.769 \\
\hline 4. State management of the accounting profession & STA & 4 & 0.708 \\
\hline 5. Corporate governance & COR & 4 & 0.735 \\
\hline 6. Economic, cultural and social conditions & ECS & 4 & 0.751 \\
\hline \multicolumn{4}{|c|}{ Dependent variable } \\
\hline IFRS application in Vietnam & APP & 5 & 0.824 \\
\hline
\end{tabular}


erage variance extracted $>50 \%$, all factor loading coefficients are greater than 0.5 and Eigen Value $>$ 1. Thus the standards, when using the exploratory factor analysis (EFA), indicate that the factors are consistent with the research data set.

\subsubsection{The results of confirmatory factor analysis (CFA)}

The model has 443 degrees of freedom; CFA shows the value of $\mathrm{p}=.000$; GFI value is 0.929 , RMSEA $=$ 0.028 is small; Chi-Square/df $=1,399$ (less than 2); $\mathrm{TFI}=0.954, \mathrm{CFI}=0.959$ are greater than 0.9 . Thus the analysis results indicate that the data is accepted with the proposed model.

Table 3. EFA test results of scales

Source: Author's research.

\begin{tabular}{l|c:c:c:c}
\hline \multicolumn{1}{c}{ Scales } & KMO & Sig & AVE & Eigenvalue \\
\hline 1. Independent variables & 0.789 & .000 & 0.54511 & 1.207 \\
\hdashline 2. Dependent variable & 0.846 & .000 & 0.58764 & 2.938 \\
\hline
\end{tabular}

Table 4. Results of assessing the reliability and convergence of scales

\begin{tabular}{|c|c|c|c|}
\hline Scales & Symbol & CR & AVE (\%) \\
\hline $\begin{array}{l}\text { 1. Legal basis for accounting } \\
\text { activities }\end{array}$ & LEG & 1.009 & 1.044 \\
\hline $\begin{array}{l}\text { Qualifications and competencies } \\
\text { of the accountant teams }\end{array}$ & ACC & 0.933 & 0.738 \\
\hline Characteristics of enterprises & ENT & 0.977 & 0.896 \\
\hline $\begin{array}{l}\text { State management of the } \\
\text { accounting profession }\end{array}$ & STA & 0.872 & 0.639 \\
\hline Corporate governance & COR & 0.966 & 0.877 \\
\hline $\begin{array}{l}\text { Economic, cultural and social } \\
\text { conditions }\end{array}$ & ECS & 0.930 & 0.772 \\
\hline IFRS application in Vietnam & APP & 0.996 & 0.978 \\
\hline
\end{tabular}

Table 4 shows that the CR reliability is greater than 0.7 , the total average variance extracted is greater than $50 \%$, so it can be concluded that the components in the scale functional quality achieve reliability and convergence. After analyzing the correlation coefficients between the pairs of factors, the study obtains the results with the highest value of 0.48 , which are all quite small and do not exceed 0.85 , so the factors meet the conditions of discriminant value.

\subsection{Testing the model and research hypotheses}

\subsubsection{Testing the research model}

SEM is used to test the existing model and research hypotheses. The estimated results of the research model show that: The testing model has 458 degrees of freedom $(p=0.00)$, and the indicators show that the model is suitable for the data collected from the market (chi-square/df $=1.837<2$; $\mathrm{GFI}=0.905 ; \mathrm{CFI}=0.910, \mathrm{TLI}=0.903$ and $\mathrm{RMSEA}$ $=0.041)$.

The main parameter estimation results reveal that both relationships are statistically significant ( $\mathrm{p}<$ $5 \%)$. Therefore, the relationship between concepts has reached theoretical expectations.

Table 5. Test results of causal relationship between concepts in the research model (not standardized)

Source: Author's research.

\begin{tabular}{|c|c|c|c|c|c|c|}
\hline \multicolumn{3}{|c|}{ Relationship } & Estimate & S.E. & C.R. & $\mathbf{P}$ \\
\hline APP & $\leftarrow$ & LEG & .185 & .048 & 3.897 & $* * *$ \\
\hline APP & $\leftarrow$ & COR & .246 & .051 & 4.807 & $* * *$ \\
\hline APP & $\leftarrow$ & ENT & .358 & .054 & 6.662 & $* * *$ \\
\hline APP & $\leftarrow$ & ACC & .426 & .053 & 8.050 & $* * *$ \\
\hline APP & $\leftarrow$ & ESC & .000 & .042 & -.006 & .995 \\
\hline APP & $\leftarrow$ & STA & -.034 & .039 & -.880 & .379 \\
\hline
\end{tabular}

Note: $* * * \mathrm{p}<0.01$.

Table 6. Test parameters in the research model (standardized)

Source: Author's research.

\begin{tabular}{|c|c|c|c|}
\hline \multicolumn{3}{|c|}{ Relationship } & \multirow{2}{*}{$\frac{\text { Estimate }}{.190}$} \\
\hline APP & $\leftarrow$ & LEG & \\
\hline APP & $\leftarrow$ & COR & .250 \\
\hline APP & $\leftarrow$ & ENT & .360 \\
\hline APP & $\leftarrow$ & $A C C$ & .459 \\
\hline APP & $\leftarrow$ & ESC & .000 \\
\hline APP & $\leftarrow$ & STA & -.043 \\
\hline
\end{tabular}

The parameters estimated (standardized) are statistically significant ( $<5 \%$ ), except for ESC and STA. Based on the weighted regression results between the concepts, it can be seen that:

- The legal basis for accounting activities (LEG), corporate governance (COR), characteristics of enterprises (ENT), qualifications and competen- 


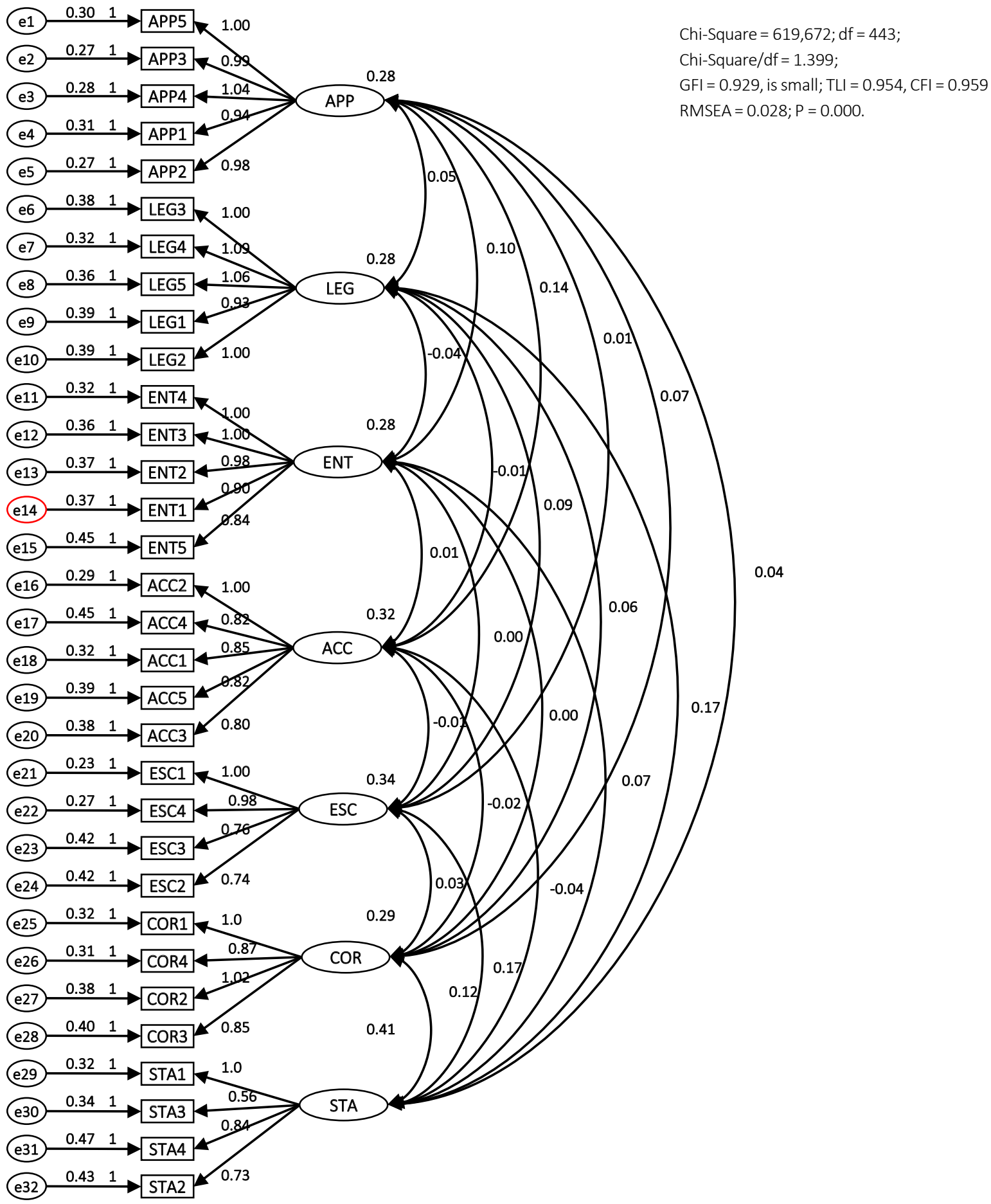

Figure 2. Standardized CFA results

cies of the accountant teams (ACC) have a positive impact on the IFRS applicability in Vietnam. Among these four factors, the most significant impact is on the qualifications and competencies of accounting teams, followed by the characteristics of enterprises, corporate governance, and legal basis for accounting activities.
Chi-Square $=619,672 ; \mathrm{df}=443$

$4, \mathrm{CFI}=0.959$

MMSEA $=0.028 \cdot P=0.000$ 


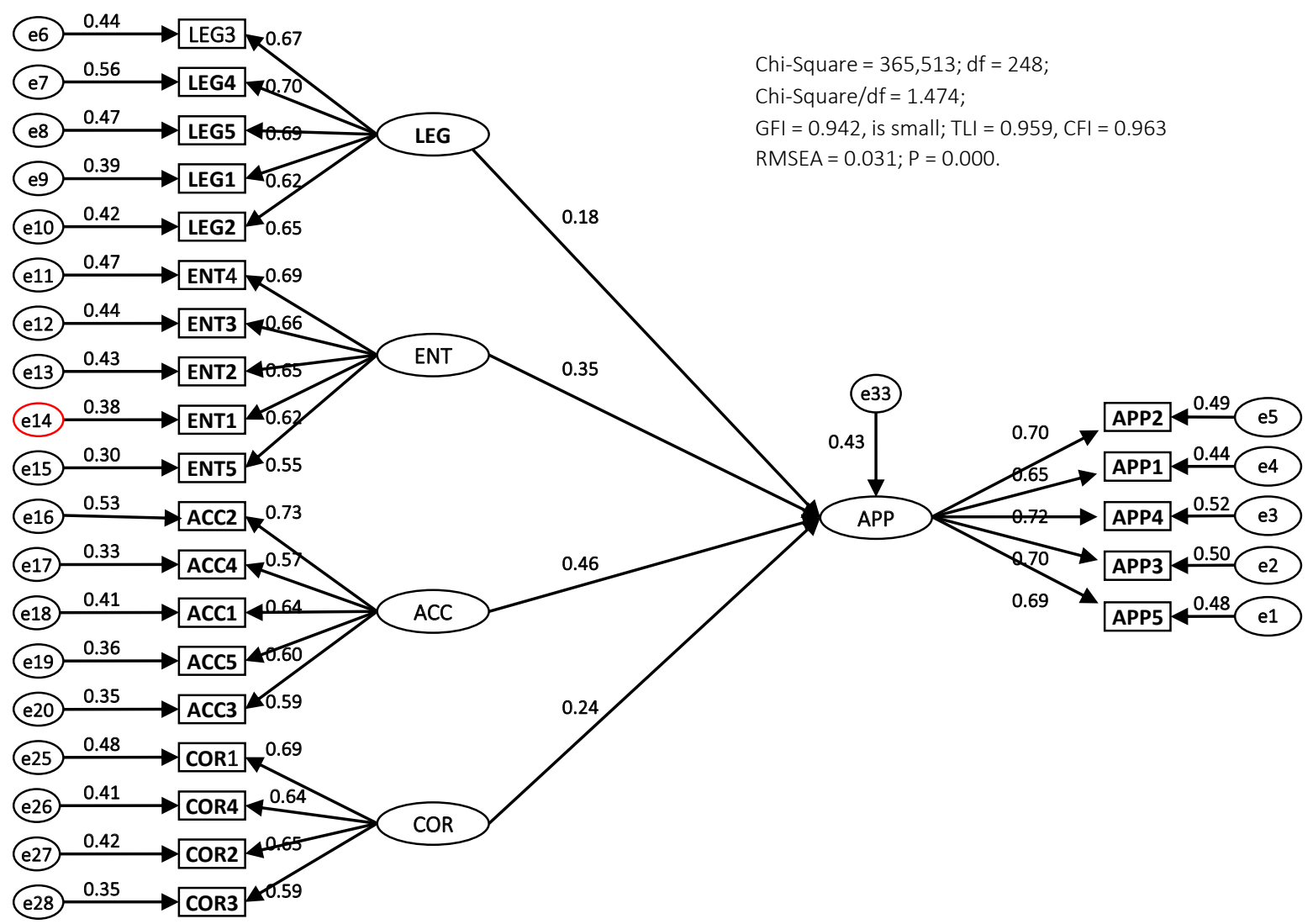

Figure 3. SEM results of the official research model (standardized)

\subsubsection{Testing research hypotheses}

The hypotheses of the research model are tested as follows (see Table 7).

Table 7. Test results of the model hypotheses

\begin{tabular}{|c|c|c|c|c|c|c|}
\hline \multicolumn{3}{|c|}{ Relationship } & \multirow{2}{*}{$\begin{array}{c}\text { Estimate } \\
.185\end{array}$} & \multirow{2}{*}{$\begin{array}{l}\text { S.E. } \\
.048\end{array}$} & \multirow{2}{*}{$\frac{\text { C.R. }}{3.897}$} & \multirow{2}{*}{$\begin{array}{c}\mathbf{P} \\
* * * \\
\end{array}$} \\
\hline APP & $\leftarrow$ & LEG & & & & \\
\hline APP & $\leftarrow$ & COR & .246 & .051 & 4.807 & $* * *$ \\
\hline APP & $\leftarrow$ & ENT & .358 & .054 & 6.662 & $* * *$ \\
\hline APP & $\leftarrow$ & ACC & .426 & .053 & 8.050 & $* * *$ \\
\hline APP & $\leftarrow$ & ESC & .000 & .042 & -.006 & .995 \\
\hline APP & $\leftarrow$ & STA & -.034 & .039 & -.880 & .379 \\
\hline
\end{tabular}

Note: $* * * p<0.01$

- $\quad$ Accept H1: Estimate $=0.185$, p-value $=0.000$. Thus, the legal basis for accounting activities (LEG) has a positive effect on the IFRS applicability in Vietnam (APP).

- $\quad$ Accept H2: Estimate $=0.246$, p-value $=0.000$. The corporate governance (COR) has a posi- tive effect on the IFRS applicability in Vietnam (APP).

- $\quad$ Accept H3: Estimate $=0.358$, p-value $=0.000$ The characteristics of enterprises (ENT) have a positive effect on the IFRS applicability in Vietnam (APP).

Accept H4: Estimate $=0.426, \mathrm{p}$-value $=$ 0.000 . The qualifications and competencies of the accountant teams (ACC) have a positive effect on the IFRS applicability in Vietnam (APP).

Reject H5: Estimate $=0.00$, p-value $=0.995$. The economic, cultural and social conditions (ECS) have a positive effect on the IFRS applicability in Vietnam (APP).

Reject H6: Estimate $=-0.034$, p-value $=0.379$. The state management of the accounting profession (STA) has a positive effect on the IFRS applicability in Vietnam (APP). 
Table 8. Results of testing the difference between the two groups of managers and auditors

Source: Author's research.

\begin{tabular}{|c|c|c|c|c|c|c|c|}
\hline & \multicolumn{2}{|c|}{$\begin{array}{l}\text { Levene's test for } \\
\text { equality of variances }\end{array}$} & \multicolumn{5}{|c|}{ T-test for equality of means } \\
\hline & $\mathbf{F}$ & Sig & $\mathbf{t}$ & df & $\begin{array}{c}\text { Sig. } \\
\text { (2-tailed) }\end{array}$ & $\begin{array}{c}\text { Mean } \\
\text { difference }\end{array}$ & $\begin{array}{l}\text { Std. error } \\
\text { difference }\end{array}$ \\
\hline Equal variances assumed & .024 & .877 & 1.242 & 498 & .215 & .06500 & .05233 \\
\hline Equal variances not assumed & - & - & 1.246 & 431.537 & .213 & .06500 & .05215 \\
\hline
\end{tabular}

Table 9. Result of testing the difference by work experience

Source: Author's research.

\begin{tabular}{l|c|c|c|c}
\hline & Sum of squares & df & Mean square & S \\
\hline Between groups & 1.706 & 4 & 427 & 1.300 \\
Within groups & 162.462 & 495 & 269 \\
Total & 164.168 & 499 & - & - \\
\hline
\end{tabular}

Consequently, the research results show that the factors affecting the IFRS applicability in Vietnam are: legal basis for accounting activities, corporate governance, characteristics of enterprises, and qualifications and competencies of the accountant teams. Among them, qualifications and competencies of the accountant teams and the characteristics of enterprises are the two factors that have the strongest impact on the applicability of IFRS in Vietnam.

\subsubsection{Testing the difference in the awareness of the IFRS applicability}

Using the nonparametric audit technique through Independent Samples, T-Test and One-Way ANOVA analysis, the following results were obtained:
Regarding the difference between the groups of business managers and auditors in the awareness of the IFRS applicability, most people think that the IFRS applicability in Vietnam is relatively high, with an average score from 4.244.30 to 5 . However, based on Table 8 and given that Sig $=0.877>0.05$, there is no significant difference between the two survey groups.

Regarding the difference in perceptions of the IFRS applicability in Vietnam, based on the work experience of the interviewees, the results shown in Table 9 indicate that Sig $=0.269>0.05$, so there is no reason to claim about the difference among the groups of interviewees divided by work experience.

\section{CONCLUSION}

The research determines factors positively impact the application of IFRS in Vietnam, namely: the legal basis, the qualifications and competencies of the accounting teams, the characteristics of enterprises and corporate governance. Among them, the one that has the strongest impact and affects the current IFRS application is the qualifications and competencies of the accounting teams, followed by the characteristics of enterprises, such as the business size, business sector and enterprises audited by Big Four. Corporate governance is also a factor that affects the applicability of IFRS at enterprises, especially the views of the owners, the operation of the board of directors and the board of management of companies. The results of the current research are similar to those of previous studies on the factors affecting the application of IFRS, such as Nguyen (2013), Hung (2016), Tran, Ha, Le, and Nguyen (2019), Thinh (2019), Khue and Oanh (2019), Hai, Tu, and Toan (2019). Nonetheless, this study also shows that the state management, especially mandatory regulation on enterprises having to be audited, enterprises audited by the Big Four; or the factor of political, economic and cultural conditions had no clear impact on the applicability of IFRS. This is also different from many studies such as Tran, Ha, Le, and Nguyen (2019), Thinh (2019), Duc, Ha, and Phuoc (2019). 
This study is conducted using the convenience sample method, so the results are of the authors' subjectivity, reducing the objectivity and generalization. Therefore, future research should consider the use of a probability sampling method, since it provides a higher degree of representation and increases the sample size for more accurate and generalized analysis. The research was conducted in Vietnam merely and covered a small period of recent years, so its results provided only short-term conclusions and recommendations. Further research can expand the scope of the survey both in space and time for a more inclusive and comprehensive assessment.

\section{AUTHOR CONTRIBUTIONS}

Conceptualization: Dung-Thi Doan, Hai-Thanh Phan.

Data curation: Dung-Thi Doan, Lan-Ngoc Thi Nguyen, Hai-Thanh Phan.

Formal analysis: Lan-Ngoc Thi Nguyen.

Investigation: Hai-Thanh Phan.

Methodology: Dung-Thi Doan.

Project administration: Dung-Thi Doan.

Resources: Dung-Thi Doan, Lan-Ngoc Thi Nguyen, Hai-Thanh Phan.

Software: Hai-Thanh Phan.

Supervision: Lan-Ngoc Thi Nguyen.

Validation: Lan-Ngoc Thi Nguyen.

Visualization: Lan-Ngoc Thi Nguyen.

Writing - original draft: Dung-Thi Doan, Lan-Ngoc Thi Nguyen, Hai-Thanh Phan.

Writing - review \& editing: Dung-Thi Doan, Lan-Ngoc Thi Nguyen, Hai-Thanh Phan.

\section{REFERENCES}

1. Adams, H., \& Linh, N. T. (2005). Vietnam's accounting and auditing regulations - Integration with international accounting and auditing principles. Vietnam: National Political Publishing House.

2. Affes, H., \& Callimaci, A. (2007). Les déterminants de l'adoption anticipée des normes comptables internationales: choix financier ou opportunisme? Comptabilité Contrôle - Audit, 2(13), 149-166. Retrieved from https://www.cairn. info/revue-comptabilite-controleaudit-2007-2-page-149.htm\#

3. Arpan, J. S., \& Radebaugh, L. H. (1985). International Accounting and Multinational Enterprises. USA: Wiley.

4. Chamisa, E. E. (2000). The relevance and observance of the IASC standards in developing countries and the particular case of Zimbabwe. International Journal of Accounting, 35(2), 267-286. https://doi.org/10.1016/ s0020-7063(00)00049-2
5. Choi, F. D., \& Meek, G. K. (2011). International Accounting (7th ed.). NJ: Prentice Hall. Retrieved from http://digilib. stiem.ac.id:8080/jspui/bitstream/123456789/191/1/International Accounting_Choi and Meek.pdf

6. Chow, C. W., \& Wong-Boren, A. (1987). Voluntary Financial Disclosure by Mexican Corporations. Accounting Review, 62(3), 533. Retrieved from https://www.jstor.org/ stable/247575

7. Cuc, N. T. K., \& Khanh, N. L. V. (2018). Factors affecting the voluntary process of applying IFRS in Vietnamese enterprises [Các nhân tố ảnh hưởng đến quá trình tự nguyện áp dụng IFRS tại các doanh nghiệp Việt Nam]. Vietnam Trade and Industry Review. (In Vietnamese). Retrieved from http://tapchicongthuong.vn/bai-viet/ cac-nhan-to-anh-huong-denqua-trinh-tu-nguyen-ap-dung- ifrs-tai-cac-doanh-nghiep-vietnam-57921.htm

8. Dayanandan, A., Donker, H., Ivanof, M., \& Karahan, G. (2016). IFRS and accounting quality: Legal origin, regional, and disclosure impacts. International Journal of Accounting and Information Management, 24(3), 296-316. https://doi.org/10.1108/ IJAIM-11-2015-0075

9. Doupnik, T. S., \& Salter, S. B. (1995). External Environment and Accounting Practice: A Preliminary Test of a General Model of International Accounting Development. The International Journal of Accounting, Education and Research, 30(3), 189-207. Retrieved from https://www. econbiz.de/Record/external-environment-culture-and-accounting-practice-a-preliminary-testof-a-general-model-of-international-accounting-developmentdoupnik-timothy/10003715209

10. Duc. P. T. H., Ha, N. T., \& Phuoc, N. T. (2019). Replace Vietnamese 
Accounting Standards (VAS) with International Financial Reporting Standards (IFRS): Is Vietnam ready? [Thay đổi hệ thống chuân mực kế toán Việt Nam (VAS) bằng chuẩn mực kế toán quốc tế (IFRS): Liệu Việt Nam có sẵn sang]. In Proceedings of the IFRS workshop-Opportunities and challenges when applying IFRS in Vietnam (pp. 54-68). (In Vietnamese). Retrieved from http://ifrsvietnam.vn/tin-tuc/ nghien-cuu-trao-doi-72/thaydoi-he-thong-chuan-muc-ketoan-viet-nam-vas-bang-chuanmuc-ke-toan-quoc-te-ifrs-lieuviet-nam-co-san-sang-188.html

11. Goodwin, J., Ahmed, K., \& Heaney, R. (2009). Corporate governance and the prediction of the impact of AIFRS adoption. Abacus, 45(1), 124-145. https:// doi.org/10.1111/j.14676281.2008.00271.x

12. Hai, P. T., Tu, C. A., \& Toan, L. D. (2019). Research on factors affecting organizational structure, operating mechanism and audit quality: An empirical study in Vietnam. Journal of Business Economics and Management, 20(3), 526545. https://doi.org/10.3846/ jbem.2019.9791

13. Hegarty, J., Gielen, F., \& Barros, H. (2004). Implementation of international accounting and auditing standards. Retrieved from http://wk.ixueshu.com/file/ c2691dda448395d6.html

14. Hung. D. N. (2016). Study the factors affecting the application of accounting standards in Vietnam. Journal of Economics and Development, 255(January 2016), 80-88. Retrieved from https://www.researchgate.net/ publication/321692118_Nghien_cuu_cac_nhan_to_anh_huong_den_viec_ap_dung_chuan_ muc_ke_toan_o_Viet_Nam

15. Jaggi, B., \& Low, P. Y. (2000). Impact of culture, market forces, and legal system on financial disclosures. International Journal of Accounting, 35(4), 495-519. https://doi.org/10.1016/s00207063(00)00076-5
16. Joshi, P. L., \& Ramadhan, S. (2002). The adoption of international accounting standards by small and closely held companies: evidence from Bahrain. The International Journal of Accounting, 37(4), 429-440. https://doi.org/10.1016/ S0020-7063(02)00190-5

17. Khue, D. H. N., \& Oanh, N. T. N. (2019). Study the factors affecting the application of international accounting standards (IAS/IFRS) [Nghiên cứu nhân tố tác động đến việc vận dụng chuẩn mực kế toán quốc tế IAS/IFRS]. In Proceedings of the IFRS workshop - Opportunities and challenges when applying IFRS in Vietnam (pp. 73-77). (In Vietnamese). Retrieved from http://ifrsvietnam.vn/tin-tuc/ nghien-cuu-trao-doi-72/nghiencuu-nhan-to-tac-dong-den-viecvan-dung-chuan-muc-ke-toanquoc-te-aisifrs-190.html

18. Kolsi, M. C., \& Zehri, F. (2013). The determinants of IAS/IFRS adoption by emergent countries (Working paper). Emirates College of Technology, Abu Dhabi. Retrieved from https:// cbe.uaeu.ac.ae/en/csafc/pdf/ ad_38.pdf

19. Martínez, J. A., Martínez, F. G., \& Diazaraque, J. M. M. (2011). Optional accounting criteria under IFRSs and corporate characteristics: Evidence from Spain. Revista de ContabilidadSpanish Accounting Review, 14(1), 59-85. https://doi.org/10.1016/ S1138-4891(11)70022-X

20. Meek, G. K., Roberts, C. B., \& Gray, S. J. (1995). Factors Influencing Voluntary Annual Report Disclosures by U.S., U.K. and Continental European Multinational Corporations. Journal of International Business Studies, 26(3), 555-572. https:// doi.org/10.1057/palgrave. jibs.8490186

21. Nguyen, T. D. K. (2013). Discuss the scale of non-financial factors affecting the application of accounting standards in small and medium-sized enterprises in Vietnam [Bàn về thang đo các nhân tố phi tài chính ảnh hưởng vận dụng chuẩn mực kế toán trong các doanh nghiep nhở va vua ở Việt Nam]. Journal of Economics and Development, 190(1), 55-69. (In Vietnamese). Retrieved from http://www.vjol. info/index.php/JED/article/ view/31778/26999

22. Nobes, C., \& Parker, R. (1995). Comparative International Accounting (9th ed.). NJ: Prentice Hall. Retrieved from http://digilib.umpalopo.ac.id:8080/jspui/ bitstream/123456789/232/1/ Comparative International Accounting.pdf

23. Phuong, L. T. H. (2019). Factors affect the adoption of the International Accounting Standards (IAS/IFRS) in Vietnam - Research on national and company level. University of Economics Ho Chi Minh City, Vietnam. Retrieved from https:// sdh.ueh.edu.vn/gop-y-luan-antien-si

24. Phuong, N. C. (2013). About the standard model - Vietnam's accounting regime [Về mô hình chuẩn mực - chế độ kế toán của Việt Nam]. Journal of Economics and Development, 194(1), 31-37. (In Vietnamese). Retrieved from http://www.vjol.info/index.php/ JED/article/view/11392

25. Phuong, N. C., \& Richard, J. (2011). Economic Transition and Accounting System Reform in Vietnam. European Accounting Review, 20(4). https://doi.org/10. 1080/09638180.2011.623858

26. Street, D. L. (2012). IFRS in the United States: If, When and How. Australian Accounting Review, 22(3). https://doi.org/10.1111/ j.1835-2561.2012.00183.x

27. Thinh, T. Q. (2019). Factors affecting the application of International Standards on Accounting by countries [Những nhân tố tác động đến việc áp dụng chuẩn mực quốc tế về kế toán tại các quốc gia]. In Proceedings of the IFRS workshop - Opportunities and challenges when applying IFRS in Vietnam (pp. 79-84). Ha Noi. (In Vietnamese). Retrieved 
from http://ifrsvietnam.vn/tintuc/nghien-cuu-trao-doi-72/ nhung-nhan-to-tac-dong-denviec-ap-dung-chuan-muc-quocte-ve-ke-toan-tai-cac-quocgia-191.html

28. Tran, T. C. T., Ha, X. T., Le, T. H. P., \& Nguyen, N. T. (2019). Factors affecting IFRS adoption in listed companies: Evidence from Vietnam. Management Science Letters, 9, 2169-2180. https://doi.org/10.5267/j. msl.2019.7.035

29. Verriest, A., Gaeremynck, A., \& Thornton, D. B. (2013). The
Impact of Corporate Governance on IFRS Adoption Choices. European Accounting Review, 22(1), 39-77. https://doi.org/10.1 080/09638180.2011.644699

30. Wallace, R. S. O., \& Naser, K. (1995). Firmspecific determinants of the comprehensiveness of mandatory disclosure in the corporate annual reports of firms listed on the stock exchange of Hong Kong. Journal of Accounting and Public Policy, 14(4), 311-368. https://doi.org/10.1016/02784254(95)00042-9
31. Zeghal, D., \& Mhedhbi, K. (2006). An analysis of the factors affecting the adoption of international accounting standards by developing countries. International Journal of Accounting, 41(4), 373-386. https://doi.org/10.1016/j.intacc.2006.09.009

32. Zehri, F., \& Chouaibi, J. (2013). Adoption determinants of the international accounting standards IAS/IFRS by the developing countries. Journal of Economics, Finance and Administrative Science, 18(35), 56-62. https://doi.org/10.1016/ S2077-1886(13)70030-1 